\title{
Preliminary studies on epidermal growth factor (EGF) immunoreactivity in goblet cells of the small intestine by a species-specific antiserum in healthy piglets and piglets with diarrhoea
}

\author{
R. Claus ${ }^{1,3}$, J. Mentschel', B. Blazey ${ }^{2}$ and O. Munz ${ }^{1}$ \\ 'Institute for Animal Husbandry and Animal Breeding, University of Hohenheim \\ Garbenstr: 17, 70599 Stuttgart, Germany \\ ${ }^{2}$ Chemisches und Veterinärmedizinisches Untersuchungsamt \\ Schaflandstr: 32/33, 70736 Fellbach, Germany
}

(Reccived 22 January 2001; accepted 20 April 2001)

\begin{abstract}
In several species the epidermal growth factor (EGF) is known to be a potent mitogen which ensures the integrity of the gut mucosa. In the pig its role in the gut was not investigated. Antisera against recombinant porcine EGF were raised in rabbits. The antiserum was used to screen EGFimmunoreactivity in histological sections of the duodenum and jejunum of healthy piglets and piglets with diarrhoea. The specificity of the staining reaction was ensured. Immunoreactivity was found in all goblet cells and their mucus but not in other cells of the gastrointestinal tract. The number of goblet cells in the duodenum of the sick animals was nearly twofold compared to healthy piglets. In the jejunum, the number of goblet cells was less strikingly increased in the piglets with diarrhoea $(20 \%)$, but the mucus granule size was 2 -fold. These data support the assumption that EGF from the goblet cells serves as a surveillance factor for gut mucosa integrity in the pig.
\end{abstract}

KEY WORDS: epidermal growth factor, pig, goblet cell, gut, diarrhoca

\section{INTRODUCTION}

The epidermal growth factor (EGF) is an acid protein with a molecular weight of $6.400 \mathrm{Da}$. It is a potent mitogen which participates in the development and

\footnotetext{
${ }^{3}$ Corresponding author
} 
maintenance of the functional integrity in many tissues (Vaughan et al., 1991; Playford and Wright, 1996). In the human species and in laboratory animals EGF could also be demonstrated in the mucous fluid of the gastrointestinal tract (Tunio and Hobsley, 1995) where the main part of EGF is derived from the mucus formation by the goblet cells (Takeyama et al., 1999). In rodents also the salivary glands contribute to the intestinal lumen content (Playford and Wright, 1996). The presence of EGF in the mucus of the intestinal tract is regarded to be an essential mechanism for intestinal ulcer healing (e.g., Wright et al., 1990; Tunio and Hobsley; 1995; Elliott et al., 2000).

For postnatal morbidity and mortality in piglets diarrhoea is one of the major causes so that an understanding of factors regulating normal gut maintenance or counteracting dysfunction is essential (Odle et al., 1996). Therefore it was our aim to rise a pig specific EGF antiserum, which is applicable for immunohistochemical studies and to screen whether EGF plays a role in the gut of healthy piglets and piglets with diarrhoea.

\section{MATERIAL AND METHODS}

\section{Source of tissue samples}

Four piglets (German Landrace $x$ Pietrain) were included in the study. They were weaned at the age of 4 weeks and were thereafter fed with a conventional piglet-prestarter. They were killed by T61 (Hoechst-Roussel, Oberschleißheim, Germany) for tissue collection at an average age of 5 weeks. Two of the piglets suffered from severe diarrhoea and had been sent to the Chemical and Veterinary Institute (CVUA, Stuttgart) for examination. The piglets showed diarrhoea, retardation of growth, and a high mortality occured in the herd. A reduced mucosa and oedema in the mesentery were observed. In one piglet $E$. coli were identified, in the other piglet additionally $\beta$-hemolizing $E$. coli and $E$. col $i$ with mucous envelopes. The other two piglets were healthy and were obtained from the specific pathogen free (SPF) University population without clinical signs of diarrhoea.

Tissue samples were taken both from the duodenum and jejunum. Fixation was performed with methanol acetic acid. After dehydration in graded ethanol the specimen were embedded in paraffine.

\section{Laboratory methods}

Recombinant porcine EGF-protein was a gift from Dr. Takagi (Higeta Shoyn Co., Japan). The antigen was prepared by coupling pEGF to bovine serum albumin. The antiserum was raised in rabbits using a standard immunization protocol. 
The radioimmunological characterization of the antisera was based on routine RIA-systems (Claus et al., 1992; Munz, 1998). The serum was diluted 1:22.000. The species-specificity was determined by comparing the calibration curves obtained with porcine, human (Calbiochem, La Jolla, USA) and murine (PromegaBoehringer, Ingelheim Products, Heidelberg, Germany) EGF. Additionally the cross reactivities were determined for the transforming growth factor $\alpha$ (TGF $\alpha)$, the insulin-like growth factor-1 (IGF-1) and insulin. For immunohistochemical use, the IgG-fraction out of $1 \mathrm{ml}$ portions of the EGF-antiserum was precipitated by sodium-sulphate. After centrifugation and washing with $18 \%$ sodium-sulphate solution, the pellet was redissolved in assay buffer.

Before staining for $\mathrm{pEGF}$, the tissue samples were deparaffinized and rehydrated conventionally and were washed in citrate buffer $(21.0 \mathrm{~g}$ citric acid monohydrate in 1:1 water, $\mathrm{pH} 6.0$ ). They were then immersed in fresh citrate buffer and heated 5 times for $5 \mathrm{~min}$ in a microwave oven. The sections were cooled for $30 \mathrm{~min}$ at $4{ }^{\circ} \mathrm{C}$. To block endogenous peroxidase, the specimen were incubated in $3 \% \mathrm{H}_{2} \mathrm{O}_{2}$ methanol for $15 \mathrm{~min}$ and were washed in aqua dest and TBS (Tris-buffer solution, $\mathrm{pH}$ 7.5). To block unspecific binding, the sections were incubated with normal sheep serum. Thereafter the EGF-IgG-solution (1:1000) in TBS was applied and incubated for $1 \mathrm{~h}$ at $37^{\circ} \mathrm{C}$. The sections were washed with TBS and covered with a biotinylated second antibody (sheep anti-rabbit IgG, Biozol, Eching, Germany) in a dilution of 1:400 in TBS for $30 \mathrm{~min}$ at room temperature. After washing in TBS, the tissues were treated with the streptavidin-biotin-horseradish-peroxidase complex (AB complex: Daco, Deisenhofen, Germany). Development was performed with diaminobenzidine (DAB; Sigma, Deisenhofen, Germany). After the final washing step, the specimen were counterstained in haemalaun. Inhibition studies were performed with irrelevant control peptides (IGF-I or insulin peptide) and pEGF peptide. The negative control was the performance of the staining procedure without the addition of the primary antibody.

From each animal 100 areas (counting fields) were randomly chosen both for the duodenum and jejunum. The cells were counted using a grid under a standardized magnification ( $x 400$ ). All goblet cells were positively stained and their percentage in the epithelium in relation to the total number of epithelial cells was calculated. Because immunoreactivity was also found in mucus vesicles of the goblet cells, the diameter of these vesicles was measured using a grid and the area was calculated under the standardized magnification.

\section{RESULTS}

No cross reactivities were found for human and murine EGF, as well as for TGF $\alpha$, IGF-1, and insulin. Neither preincubation with IGF-1 nor insulin did inhi- 
bit the immunohistochemical staining reaction, whereas preincubation of the antibodies with a surplus of pEGF peptide inhibited staining. The negative control did not lead to any staining.

Both in the duodenum and jejunum the immunoreactivity was limited to the goblet cells and their mucus (Figure 1). Neither enterocytes in the mucosa nor plasma cells and fibroblasts revealed immunostaining. A moderate staining of the mucus granules indicated their EGF-content (Figure 1). The quantitative evaluation was separately performed for the duodenum and jejunum (Table 1). In the

TABLE 1

Characterization of EGF in the duodenal and jejunal mucosa of healthy piglets and piglets with diarrhoea

\begin{tabular}{llcc}
\hline Site & Animals & $\begin{array}{c}\text { \% EGF-positive cells } \\
\text { mean } \pm \text { SE }\end{array}$ & $\begin{array}{c}\text { Area of mucus granules } \\
\mu \mathrm{m}^{2}\end{array}$ \\
\hline \multirow{2}{*}{ Duodenum } & Healthy & $13.73 \pm 0.80$ & $0.70 \pm 0.05$ \\
& Diarrhoea & $22.80 \pm 0.78$ & $0.95 \pm 0.04$ \\
\multirow{3}{*}{ Jejunum } & Healthy & $10.7 \pm 0.61$ & $0.55 \pm 0.05$ \\
& Diarrhoea & $12.73 \pm 0.61$ & $1.10 \pm 0.04$ \\
\hline
\end{tabular}

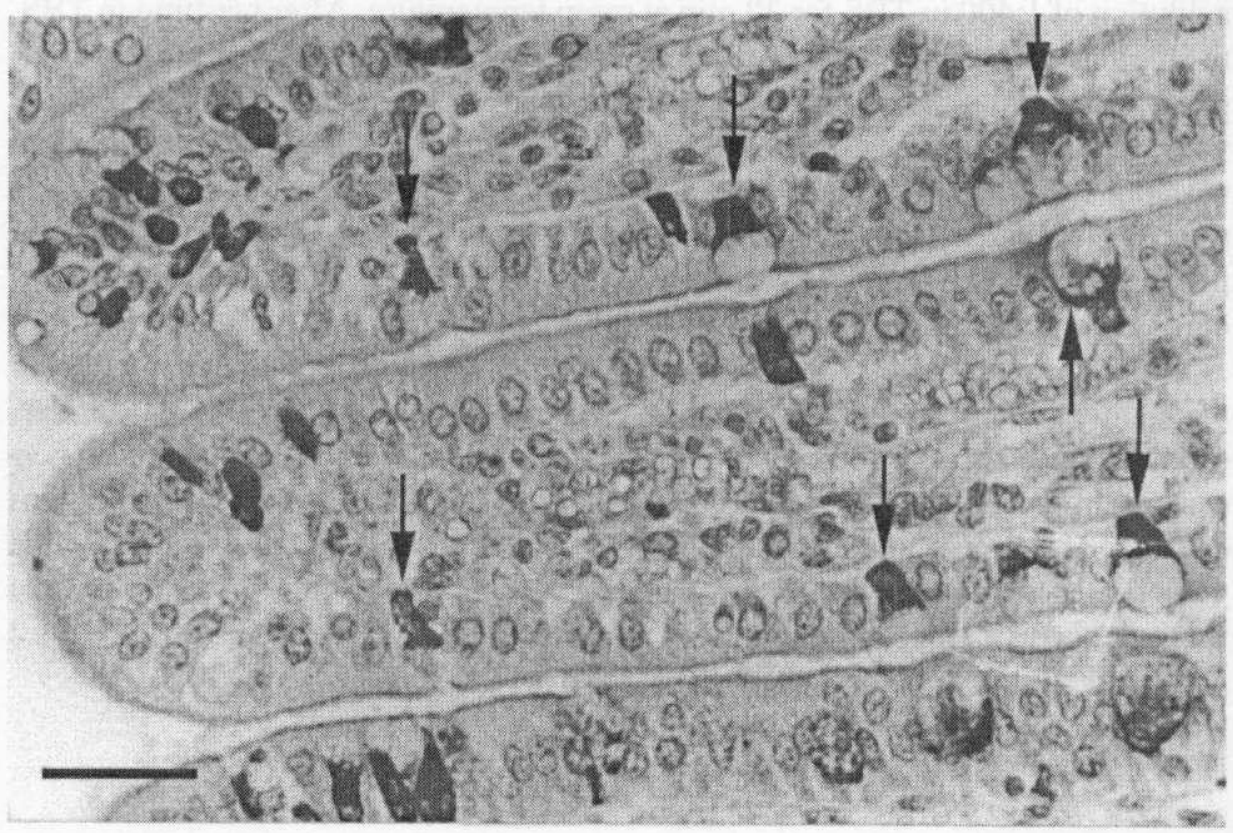

Figure 1. Immunohistochemical localization of pEGF (arrows) in the duodenum of a healthy piglet.

The large mucus bubbles of the goblet cells are visible $(\mathrm{bar}=36 \mu \mathrm{m})$ 
duodenum the total number of goblet cells and thus the percentage of positive cells was higher compared with the jejunum both for the healthy and the ill piglets. Nearly twofold numbers of goblet cells could be demonstrated in the ill animals compared to the healthy piglets in the duodenum. This difference probably is due to the health status because the two piglets in each group revealed similar values (healthy: $13.82 \%$ and $13.65 \%$ EGF positive cells, respectively; diarrhoea: 23.08 and $23.49 \%$ ). In the jejunum neither the size of the goblet cells nor the number of total enterocytes per visual field were influenced by the health status, but the activity in the mucus area of the goblet cells was increased (healthy: 1.22 and $0.98 \mu \mathrm{m}^{2}$; diarrhoea: $0.55 \mu \mathrm{m}^{2}$ in both piglets). Whereas the number of goblet cells in the jejunum of the ill piglets was only moderatly higher than in the healthy animals, the activity was nearly 2 -fold in the ill animals.

\section{DISCUSSION}

Earlier attempts to demonstrate enterocyte EGF production in the pig failed (Jaeger and Lamar, 1992) due to the low cross reactivity of the antibodies directed towards recombinant human EGF. Therefore, the demonstration of EGF in the pig goblet cells and their dependency on the health status are the first data obtained with an antiserum directed against porcine EGF. Even if only 2 piglets could be included in each health group, the data in the healthy piglets suggest that EGFproduction occurs in all goblet cells. These cells are more frequent in the duodenum (13.73\% of enterocytes) compared to the jejunum (10.7\%). Staining was also present in the mucus granules in the goblet cells, so that the mucus layer over the intestinal epithelium is likely to form a reservoir of EGF. In the piglets with diarrhoea the frequency of goblet cells in the duodenum was nearly twofold compared with the healthy animals in the duodenum and the area of the mucus granules was increased by about $25 \%$ so that the total amount of EGF-containing mucus was remarkably increased. The volume of mucus seems to be stimulated by EGF itself, because perfusion of the lumen with EGF alone stimulated mucus secretion from goblet cells in rats (Ishikawa et al., 1994).

The increase of both the number of goblet cells and their functional status due to diarrhoca, fits to the suggested role of EGF as a surveillance peptide which is readily available to stimulate repair at sites of injury (e.g., Petschow et al., 1993; Playford et al., 1996). The fact that EGF is acitve only when the integrity of the gut is incomplete such as in newborn animals and at sites of injury, probably is explained by the location of the EGF-receptor in the basolateral membranes of the human and porcine gut (Kelly et al., 1992; Playford et al., 1996). A mitogenic effect of EGF on intestinal stem cells in the basolateral compartment is known and may involve both the formation of enterocytes and goblet cells (Kong et al., 1998). 


\section{ACKNOWLEDGEMENT}

We thank Dr. Takagi, Japan, for the rpEGF. The help of Dr. Lohner and Dr. Süß-Dombrowski for necropsy, selection of the piglets, and diagnosis is appreciated. We also thank Helga Hägele vor skillful technical assistance and Birgit Deininger for typing the manuscript.

\section{REFERENCES}

Claus R., Weiler U., Hofäcker S., Herzog A., Meng H., 1992. Cycle dependent changes of growth hormone $(\mathrm{GH})$, insulin-like growth factor $\mathrm{I}(\mathrm{IGF}-\mathrm{l})$ and insulin in bloodplasma of sows and their relation to progesterone and oestradiol. Growth Regulat. 2, 115-121

Elliott S.N., Wallace J.L., McKnight W., Gall D.G., Hardin J.A., Olson M., Buret A., 2000. Bacterial colonization and healing of gastric ulcers: the effects of epidermal growth factor. Amer. J. Physiol.Gastrointest. L. 278, G105-G112

Ishikawa S., Cepinskas G., Specian R.D., Itoh M., Kvietys P.R., 1994. Epidermal growth factor attenuates jejunal mucosal injury induced by oleic acid: role of mucus. Amer. J. Physiol. 267, G1067-77

Jaeger L.A., Lamar C.H., 1992. Immunolocalization of epidermal growth factor (EGF) and EGF receptors in the porcine upper gastrointestinal tract. Amer. J. Vet. Res. 53, 1685-1692

Kelly D., McFadyen M., King T.P., Morgan P.J., 1992. Characterization and autoradiographic localization of the epidermal growth factor receptor in the jejunum of neonatal and weaned pigs. Reprod. Fert. Develop. 4, 183-191

Kong S.E., Heel K., McCauley R., Hall J., 1998. The role of enterocytes in gut dysfunction. Pathol. Res. Pract. 194, 741-751

Munz O., 1998. Untersuchungen zur Regulation und Sckretion des epidermalen Wachstumsfaktors (EGF) und des insulinartigen Wachstumsfaktors I (lGF-I) in der Milchdrüse der Ziege. Diss. Rer. Nat., Hohenheim University (Germany)

Odle J., Zijlstra R.T., Donovan S.M., 1996. Intestinal effect of milkborne growth factors in neonates of agricultural importance. J. Anim. Sci. 74, 2509-2522

Petschow B.W., Carter D.L., Hutton G.D., 1993. Influence of orally administered epidermal growth factor on normal and damaged intestinal mucosa in rats. J. Pediat. Gastroenterol. Nutr. 17, 49-58

Playford R.J., Hauby A.M., Gschmeissner S., Pfeiffer L.P., Whrigth N.A., McGarrity T., 1996. The epidermal growth factor receptor (EGF-R) is present on the basolateral, but not the apical, surface of enterocytes in the human gastrointestinal tract. Gut 39, 262-266

Playford R.J., Wright N.A., 1996. Why is epidermal growth factor present in the gut lumen? Gut 38, 303-305

Takeyama K., Dabbagh K., Lee H.M., Agusti C., Lausier J.A., Ueki I.F., Grattan K.M., Nadel J.A., 1999. Epidermal growth factor system regulates mucin production in airways. Proc. Nat. Acad. Sci. USA 96, 3081-3086

Tunio A.M., Hobsley M., 1995. Epidermal growth factor in saliva and gastric juice: response to histamin. Gut 37, 335-339

Vaughan T.J.U., Pascall J.C., James P.S., Brown K.D., 1991. Expression of epidermal growth factor and its mRNA in pig kidney, pancreas and other tissues. Biochem. J. 279, 315-318

Wright N.A., Pike C., Elia G., 1990. Induction of a novel epidermal growth factor-secreting cell lineage by mucosal ulceration in human gastrointestinal stem cells. Nature $343,82-85$ 


\section{STRESZCZENIE}

Wstępne badania nad immunoreaktywnym nablonkowym czynnikiem wzrostu (EGF), przy użyciu specyficznych gatunkowo przeciwcial w komórkach kubkowych jelita cienkiego u prosiąt zdrowych i prosiąt $z$ biegunką

U wiclu gatunków zwierząt stwicrdzono, że nabłonkowy czynnik wzrostu (EGF) jest potencjalnym mitogenem zapewniającym ciągłość śluzówki jelita cienkiego. Jego rola w jelicie świń nie była badana. Opisane badania dotyczą metody oznaczania EGF u tego gatunku zwierząt. Przeciwciała anty-EGF gatunkowo-specyficzne dla świń otrzymano poprzez immunizację królików rekombinowanym świńskim EGF. Obecność immunoreaktywnego EGF stwierdzono w komórkach kubkowych dwunastnicy i jelita czczego. U chorych prosiąt liczba komórek kubkowych dwunastnicy była dwukrotnie większa niż u zwierząt zdrowych. W jelicie czczym różnice te wynosiły około $20 \%$, natomiast powiększona była dwukrotnie średnica granul śluzowych.

Wyniki potwierdzają tezę, że EGF komórek kubkowych odpowiada za ciagłość śluzówki jelita u świń. 